九州大学学術情報リポジトリ

Kyushu University Institutional Repository

\title{
A Study on Risk-Sharing Scheme of Formal Contract Agreements in Swine Industry in Vietnam
}

DONG, Dzung, Dao

Laboratory of Food Marketing and Distribution, Graduate School of Bioresource and Bioenvironmental Sciences, Kyushu University

MORITAKA, Masahiro

Laboratory of Food Marketing and Distribution, Faculty of Agriculture, Kyushu University

LIU, Ran

Laboratory of Food Marketing and Distribution, Faculty of Agriculture, Kyushu University

FUKUDA, Susumu

Laboratory of Food Marketing and Distribution, Faculty of Agriculture, Kyushu University

https://doi.org/10.5109/2339034

出版情報：九州大学大学院農学研究院紀要. 64 (2)，pp. 395-405，2019-09-02. Faculty of Agriculture, Kyushu University

バージョン :

権利関係 : 


\title{
A Study on Risk-Sharing Scheme of Formal Contract Agreements in Swine Industry in Vietnam
}

\author{
Dao Dzung DONG ${ }^{1,2}$, Masahiro MORITAKA, Ran LIU and Susumu FUKUDA* \\ Laboratory of Food Marketing and Distribution, Faculty of Agriculture, Kyushu University, \\ 744 Motooka, Nishi-ku, Fukuoka-shi, Fukuoka, 819-0395, Japan \\ (Received May 7, 2019 and accepted May 8, 2019)
}

\begin{abstract}
Although Vietnam is ranked as the world's largest pig producers and the global pork consumption country, its swine and pork industry have been at the beginning of modernization. Swine producers, which dominate by small-scale farmers, are suffering from a number of risks. Participation in formal contract farming is one of the mitigation strategies. This study aims at summarizing the main risks of different scales pig farmers and analyzing how they have been overcome insights the contract agreements. Through the review of previous works, using time series database and in depth-interviews, results have been found as follows. Contract agreements in swine sector are the applications of ones in developed countries, which have been amended to fit Vietnam's circumstance. Production management and marketing contracts have specific terms to share almost staple risks of independent small-scale producers like the price of hog and animal feed, utilization of breeds, feeding, and related technical production. It prevents the systematic risk of epidemic diseases through bio-control solutions of the large- and mega-farms. Marketing contract brings benefit for processors in terms of cost reduction by ensuring steady large flows of uniform live hog inputted. The majeure case is identified, although it is the un-specific rule. Contract agreement retains its limitation, as a non-market instrument, in mitigating with correlated risks. It cannot cover systematic effect to contractors like epidemic diseases, variation in the domestic hog price, the volatility of international market price of staple materials for animal feed production and/or the compound-risks created by the combination of those. However, this scheme is considered as an essential instrument for risk mitigation given the fact that agricultural insurance, future contract, options, or other financial tools do not exist in Vietnam. The contract agreement, vertical integration or coordination are the ways to boost the development of swine industry in the developing countries.
\end{abstract}

Key words: contract farming, swine, pork, risk, Vietnam

\section{INTRODUCTION}

Data figure of the FAOSTAT (2018) put Vietnam on the top sixth countries worldwide producing the highest number of pigs in term of 1994-2017. The Country was also the world's second per-capital pork consumption per year that was triple the global average with a 30.4 kilogram (OECD, 2018). Pork is the staple meat in Vietnamese diet comparing to the others (T. Hao Nguyen, Nguyen, Kabango, \& Pham, 2018). Unlike the developed world's largest producers, the proportion of hog for domestic serving was the main part that was account for 75.0\% (IPsos, 2017). Small-scale producers are still dominating the supply sides (Giap, 2015). They have suffered from the number of risks regarding production, marketing, financial or human risks. Participation in both formal and informal contracts farming is considered as one of the appropriate mitigations of risks (Tran \& Nguyen, 2012).

The foreign direct investment (FDI) companies in the animal feed industry of Vietnam have offered the first contracts in swine in the year 2000s. It is economic institution wherein the firm as contractor delegates the

\footnotetext{
1 Laboratory of Food Marketing and Distribution, Graduate School of Bioresource and Bioenvironmental Sciences, Kyushu University

2 Vietnam National University of Agriculture, Vietnam

* Corresponding author,(Email: sufukuda@agr.kyushu-u.ac.jp)
}

production of hog and sows to the contractee. Thereafter, it has been targeted as one of the measures to promote vertical integration in agricultural value chains since 2002 and been potentially purported for the restructure of agro-food governance of the Country in the future. In accompany with those changes, contract forms and types have been amended following the modernization of agro-food value chain. Consequently, criteria for participants and key articles have also been adjusted. This raises the rationale of investigating detail contents of formal contract agreement to confirm its role as risks mitigation of swine farmers. The structure of the study as follows: Firstly, we summarized the recent trends of the swine industry of Vietnam and restated the definition of a formal contract. Next, we revised the risks of swine producers that were covered in the formal contract agreements. Lastly, the pros and cons of formal contract agreement as an instrument of risk mitigation were analyzed.

\section{RESEARCH METHODS AND DATA COLLECTION}

\section{Data collection}

To provide insights into formal contract contents, this study used both secondary data and primary data. The secondary data were achieved mainly for review works. Its sources included worldwide publications and related documents in Vietnamese like procurements, 
project data, research reports, and papers. Databases on the prices collected from the Vietnam Customs Office and AgroInfor (a state-own research institution). Primary data consisted of practical surveys and in-depth interviews with the key-person from companies and farmers in March 2018 and March 2019.

\section{Analysis method}

Firstly, purposing the map of risks, this study recalculated frequencies, the magnitude of risks and mapped the risks through the application of heat map. Secondly, the average nominal monthly retail price of hogs in the Country was computed using data of observed provinces. Thereafter, it was converted into the real price in relation to the inflation rate and Consumption Price Index (CPI). Variation of both was taken via the growth-rate calculation.

\section{RESULTS AND DISCUSSION}

\section{Reviewing contract farming scheme swine industry of Vietnam}

Structure changes in the swine-to-pork industry in Vietnam

Since the first introduction of compound animal feed in Vietnam in 1991 by the FDI companies, the number of pig heads enjoyed a twofold rise within ten years (Dong, Liu, Moritaka, \& Fukuda, 2018a). After the first bloom in the industrial, formal contract farming had been introduced. Accompany with conglomeration in the agrofood sector, which notably occurred in around 2015, these become the backbone of three of paradigms of vertical coordination in the modernized agro-food industry that named the full- and semi-integrated hierarchy model and the cooperated hierarchy model (Dong, Liu, Moritaka, \& Fukuda, 2018b). The bilateral production management contract is used in the first two models, which forms the so-called win-win constellation for both contractor and contractee. Bilateral marketing contract-basis is used by actors involved in the following one. This brings the win-for-three parties scheme (the contractor, contractee and supporting institution). Agreements' key straits are shown in Table 1.

Informal contracts between farmers and cooperatives, or input/output traders are dominant. For indigenous varieties, which made up 7\% of the national herd in 2014 (Giap, 2015), informal contracts were found to exist between pig producers and output traders. The existence and persistence of informal contracts are based mainly on social capital and trust. The repeated satisfactory transactions between actors reduce uncertainty and build reputation, thereby also effectively deduct transaction costs (Costales \& Catelo, 2008). In 2018 , around twenty of leading companies of total 250 animal feed firms in the Country have been offering formal contract agreements (including sows and hogs farms). We emphasize on the aspect that the formal scheme contributes as an instrument of risk mitigation from the view of both parties.

\section{Defining the formal contract agreement in the swine sector}

According to Dong, Moritaka, \& Fukuda, (2015) the definition of hog production management contract follows the one proposed by Prowse (2012). This is " $a$ contractual arrangement for a fixed term between a farmer and a firm, agreed verbally or in writing before production begins, which provides resources to the farmer and/or specifies one or more conditions of production, in addition to one or more marketing conditions, for swine production on land owned or controlled by the farmer, which is non-transferable and gives the firm, not the farmer, exclusive rights and legal title to the production process". The recent

Table 1. Different straits of formal contract agreements

\begin{tabular}{|c|c|c|c|}
\hline & \multirow{2}{*}{$\begin{array}{l}\text { Bilateral marketing-basis } \\
\text { contract }\end{array}$} & \multicolumn{2}{|c|}{ Bilateral production management contract } \\
\hline & & Full contract (domestic) & Full contract (FDI) \\
\hline Involvers & $\begin{array}{l}\text { Processors vs } \\
\text { Farmers (or producers) }\end{array}$ & $\begin{array}{l}\text { Animal feed firms vs } \\
\text { Farmers (or producers) }\end{array}$ & $\begin{array}{l}\text { Animal feed firms vs } \\
\text { Farmers (or producers) }\end{array}$ \\
\hline $\begin{array}{l}\text { Scale or farm } \\
\text { size }\end{array}$ & $\geq 300$ hogs & $\begin{array}{l}\geq 500 \text { hogs (normal) } \\
\geq 10,000 \text { hogs (mega scale in } \\
\text { leasing contract) }\end{array}$ & $\begin{array}{l}\geq 500 \text { hogs (before } 2016 \text { ) } \\
\geq 1000 \text { hogs (after } 2016 \text { ) } \\
\geq 10,000 \text { hogs (for rent) }\end{array}$ \\
\hline Land areas & Unspecified & $\begin{array}{l}\geq 1 \text { ha, flexible; } \\
\geq 10 \text { ha (leasing contract) }\end{array}$ & $\begin{array}{l}\geq 1 \text { ha (before } 2016 \text { ), } \geq 2 \text { ha } \\
\text { (after 2016); } \geq 10 \text { ha (for rent) }\end{array}$ \\
\hline $\begin{array}{l}\text { Number of } \\
\text { farms }\end{array}$ & $\begin{array}{l}25 \text { farms in Northern Vietnam, } \\
2018\end{array}$ & $<2000$ farms, in expanding & $\begin{array}{l}\text { Before 2016: increasing, after } \\
\text { 2016: opposite trends: } \\
\text {-Reducing: dominated firms } \\
\text { - Rising: new-entry firms }\end{array}$ \\
\hline $\begin{array}{l}\text { Monitoring } \\
\text { scheme }\end{array}$ & $\begin{array}{l}\text { Government involves, } \\
\text { consultancy agent, contractor's } \\
\text { staffs, contract validation }\end{array}$ & $\begin{array}{l}\text { Valid contract, technical staff, } \\
\text { managing evaluation }\end{array}$ & $\begin{array}{l}\text { Valid contract, technical staff, } \\
\text { managing evaluation }\end{array}$ \\
\hline Price control & Flexible references price & Fix compensate & Fix compensate \\
\hline
\end{tabular}


development of contract agreement extends an additional to term 'providing resources' to become “..., which provides resources (with or without specifying an endowing value) to the farmer and/or...". In this case, the contractor provides resources (animal feed, drugs, facilities) to the farmer at the rational price to encourage them utilizing effectively resources. Contractor retains the control over types, quantity, and quality of inputs. The bilateral marketing-basis contract fulfils this definition, but marketing terms are defined as more specific than the production management contract.

The definition above distinguishes from an operational leasing agreement that has offered by the animal feed firms in the country recently. The leasing agreement is an extreme case of the formal production management contract, in which "the farmer and/or investor delegates swine production to the firm to focus on the legal controlling large-scale land and owning facilities like housing, farm infrastructure rather than hiring labor for a long-term operation that is fully managed by the firm". In the country context, controlling exceed four hecta of land requires complicated procedures to the holders, which are appropriate to an investor than a small-scale farmer. Leasing contract aims at building swine farm at mega-capacity (more than ten thousand of hogs or at least two thousand sows) in the Country. The period of a first leasing contract between two parties last at least fifteen years whistles the first normal contract agreement has been fiveyears.

\section{Risks of swine farmers: a country review}

\section{Risk analysis of hog producers}

The first systematic analysis of risks of the main actors involving in the swine and pork industries of Vietnam has conducted by (Tran, Nguyen, Le, \& Nguyen, 2011) through a national funding program. In the studies, authors have quoted the definition of risk according to Hardaker et al. (1997) and the first version of Hardaker, Lien, Anderson, \& Huirne, (2015). The term 'risk' could be interpreted in three common ways: i) the chance of a bad outcome; ii) the variability of outcomes, i.e. the converse of stability; and iii) uncertainty of outcomes. Agricultural risk is divided into production risk, price or market risk, institution, human, and the financial risk (risk of debt, using credit, change in the inflation rate or negative effect from the lenders and borrowers).

Risk analysis of swine farmers published by (Tran \& Nguyen, 2012) has mapped in Figure 1. This figure ranks seven popular types of risks that swine producers facing difference sizes during the first three years (2007-2009) since Vietnam joining the World Trade Organization (WTO). The frequency of occurrence was the number of farmers had suffered at least one of the identified risks in the last three years. The magnitude of single risks was evaluated based on the annual value of losses (in million VND). The farm size included the large size (more than 50 pig heads per household per year), medium size (20-50 pig heads/HH/year) and small scale (less than 20 pig heads/HH/year). Pig disease and risk of hog price variation affect mainly producers at any scale, followed by the risk of using animal feed, insemination technique and others regarding technical issues of the production process. The authors have also marked the compound-risk that is an interrelation between the reduction of hog price and the losses caused by a disease outbreak. It creates a stacked negative impact on producers.

At the local (provincial) level, Nghi, Anh, Oanh, \& Phong (2013) analyze agricultural risks of swine production of households in southern Vietnam (Can Tho city) reasserts the influence of production risk, market, and financial risks. In the Northern of the Country, (Huong \& Nanseki, 2015) conducted research to reveal the small-scale producers' perception of risks (78.3\% of respondents raising less than 50 hogs per cycle). The results confirm that the price of pork, epidemic diseases, and production costs are the most important risks. Using the Principal Component Analysis, hypothesis items were classified into six categories including human and environment, information, market access, financial situation, production, and price volatility. The experience producers would rather care about information and market access risk than the financial one. The farmers, who invest more for swine production are less concern with human and environment hazard.

Researchers have also paid attention to the type of disease, how it has been spread out into the larger areas, and behaviors of small-scale farmers toward the epidemic disease (T. T. H. Nguyen \& Pham, 2016; Pham et al., 2017). The results show that common diseases at weaning ages are more frequent than that of the fattening in every cycle. Farmers rely on self-experiences and advice from the local veterinarians to solve this so-called individual single risk. However, the systematic (or interregional) dispersion of disease, which is explained in Figure 3, 4 show the most important problem to both small- and large-scale producers. Investigating the financial impact of the most frequent disease, H.T.T. Pham et al. (2017) calculated the percentage of the losses (including the direct and indirect cost) per total gross margin (GM) of pig holding. The losses (in period 2013-2014) per pig holding due to PRRS (the Porcine Reproductive and Respiratory Syndrome) were the highest, accounting for $41 \%$ of total 18,846 USD of GM for large farm, 38\% of amount 7,014 USD for fattening farm and $63 \%$ of the value 2,350USD for the smallholders. The cost incurred by Foot Mouth Disease (FMD) was lower with $19 \%, 25 \%$ and $32 \%$ of GM of pig holding in a large farm, fattening farm and smallholder, respectively. The cost of epidemic diarrhea was the lowest compared to losses due to PRRS and FMD and accounted for around $10 \%$ of GM of pig holding in the three swine farming groups. Studies also remark about the intervention and surveillance policies of the Government in response to the targeted epidemics. Paying commitment, compensation scenarios, and communication affect directly to the reaction of swine producers to report risks for culling instead of selling to the market. 


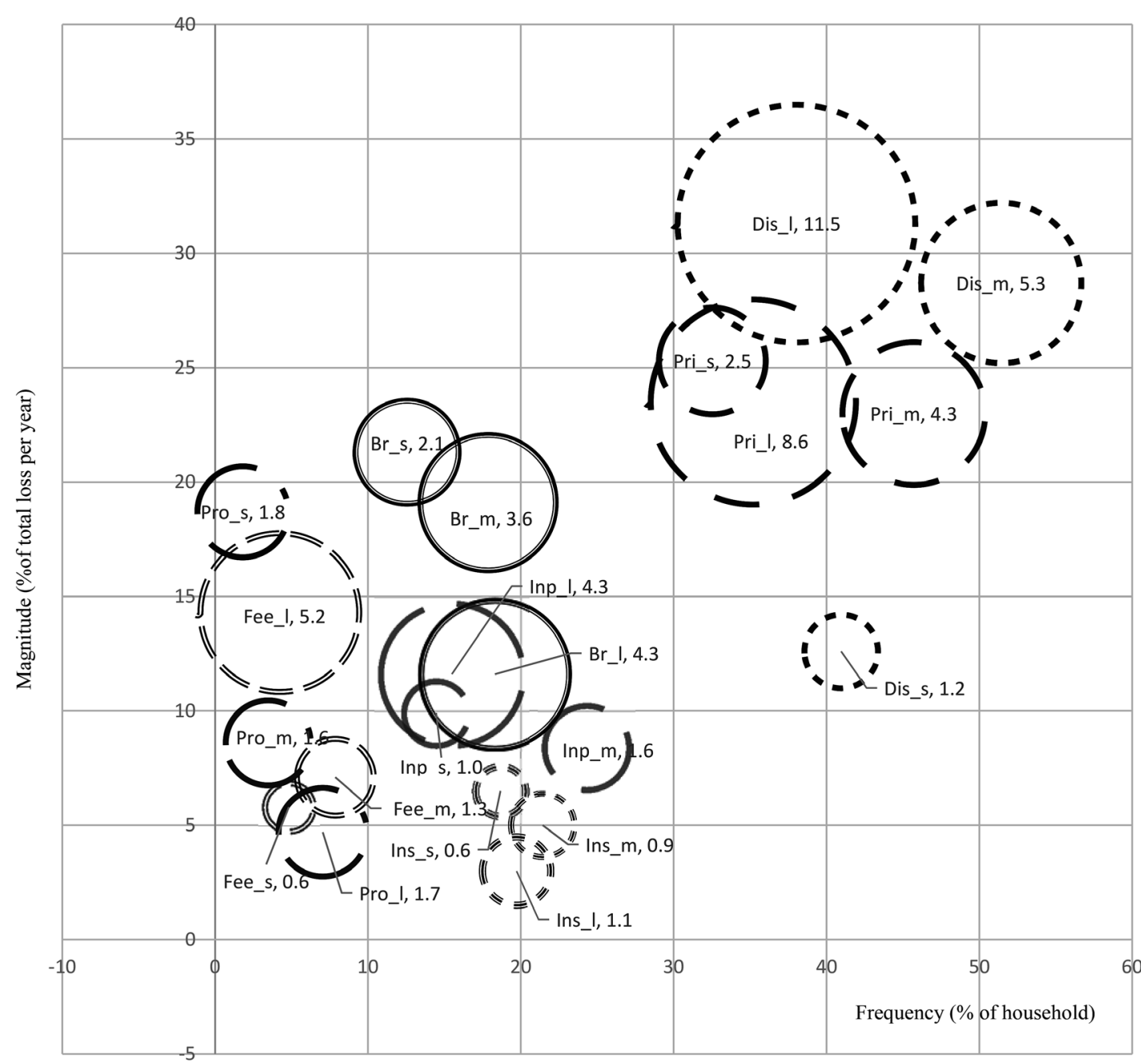

Legend: Abbreviation name of risks: Risk of breeding (Br_), Disease (Dis_), Feeding (Fee_), Production risk (Pro_), Insemination (Ins_), Input price (Inp_), and hog price (Pri_) combine with the farm-scale. Farmsize include small-scale (_s), medium scale (_m) and large-scale (_l). For example, in Figure, abbreviation 'Dis_s,6.0' denotes the average damage of a small-scale farm caused by Disease was 6.0 million VND in the year 2009 .

The bubble' area shows the actual average loss value (in million Vietnam Dong) of a farm per year in 2009. Source: Synthesized from Tran. D. T et al. 2012

Fig. 1. Mapping the risks of swine producers in Vietnam.

In order to illustrate the market risk, Tran \& Nguyen, (2012) analyzed the variation of the hog price, animal feed and its staple ingredients in the period of 2007-2010. A time-series data (2001-2017) of average retail price (nominal and real price) of live hog at weight over $80 \mathrm{~kg}$ in Vietnam has shown in Figure 2. It reveals the long-term trend with cyclical, seasonal and random variation of both types of hog price. The contractors that holding a large number of hogs are the most concerned with these variations of prices. This is an apart of the compound risk, which refers to the down-trend of hog price during the effective period of diseases. In some cases, the hog prices at border-gate reported by the frontier hog traders are the important references to decide the wholesale price of live hogs. As subsidiaries of animal feed firms, swine contractors concern the price variation of ingredients for animal feed production, especially, ones play as independent departments of the belonging animal feed corporations.

\section{Coping with the risk of swine producers}

According to (OECD, 2009) several possible farm risk management instruments and strategies include risk reduction, risk mitigation and risk coping. From the view of small-scale producers, coping with risks are conducted mainly at farm-level regarding the informal scheme instead of market-based instruments. Both small- and large-scale farmers pay attention on disease prevention and mitigation (including the improvement of husbandry technique), reduction of market risk (encompassing market access and information), production risk (reducing production cost), financial risks (interest rates and loans), and diversification of income (Tran \& Nguyen, 2012; Thi Huong Nguyen, Nanseki, \& Chomei, 2016; Hoa T T Pham et al., 2017). However, the solutions emphasize the production technique for disease 


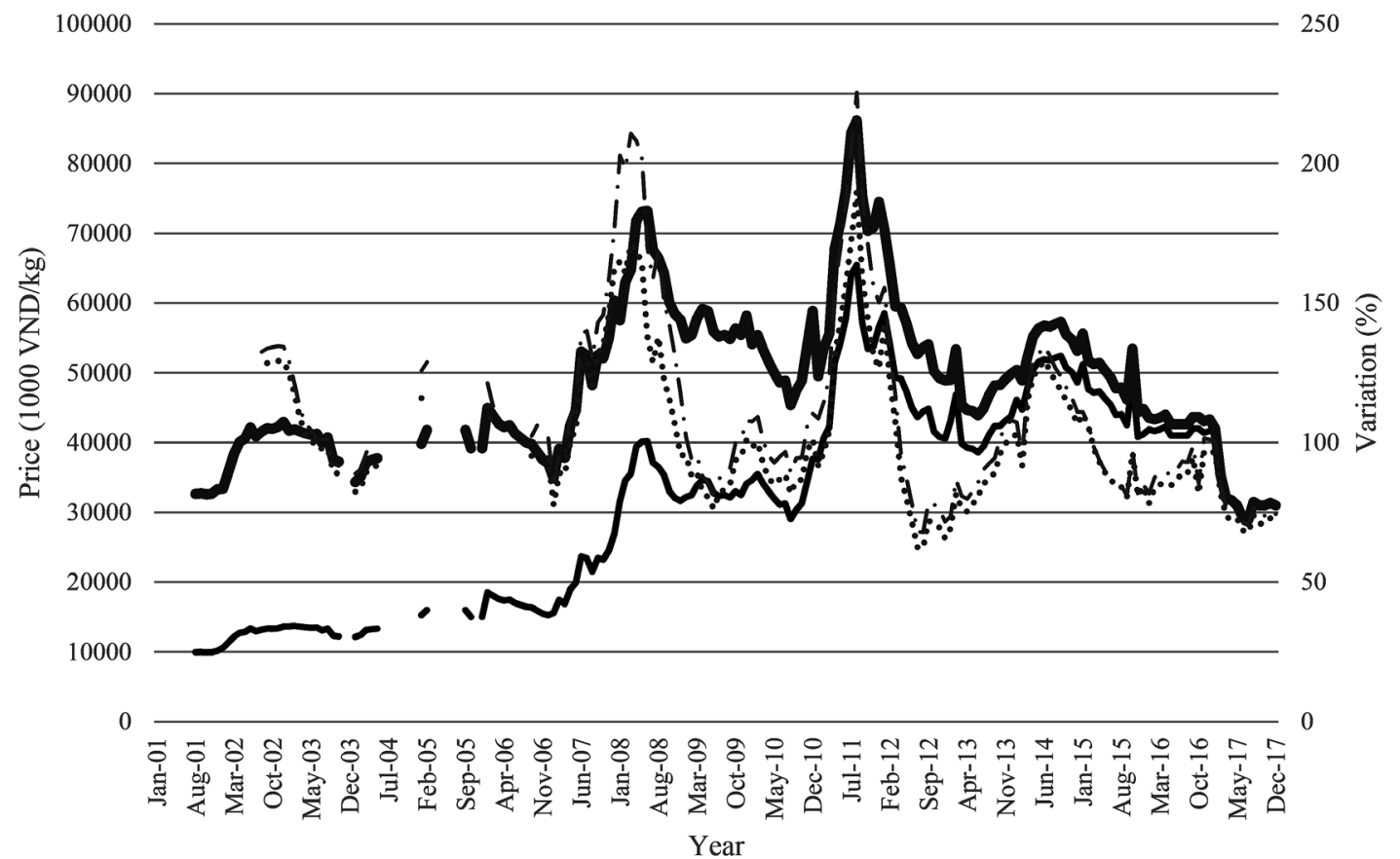

$\longrightarrow$ hog retail price_nominal $\longrightarrow$ hog retail price_real $-\cdots-$ Price variation_nominal $\cdots . .$. price variation_real

Fig. 2. Variation and average retail hog price (at the weight above $80 \mathrm{~kg}$ ) in Vietnam, 2001-2018.

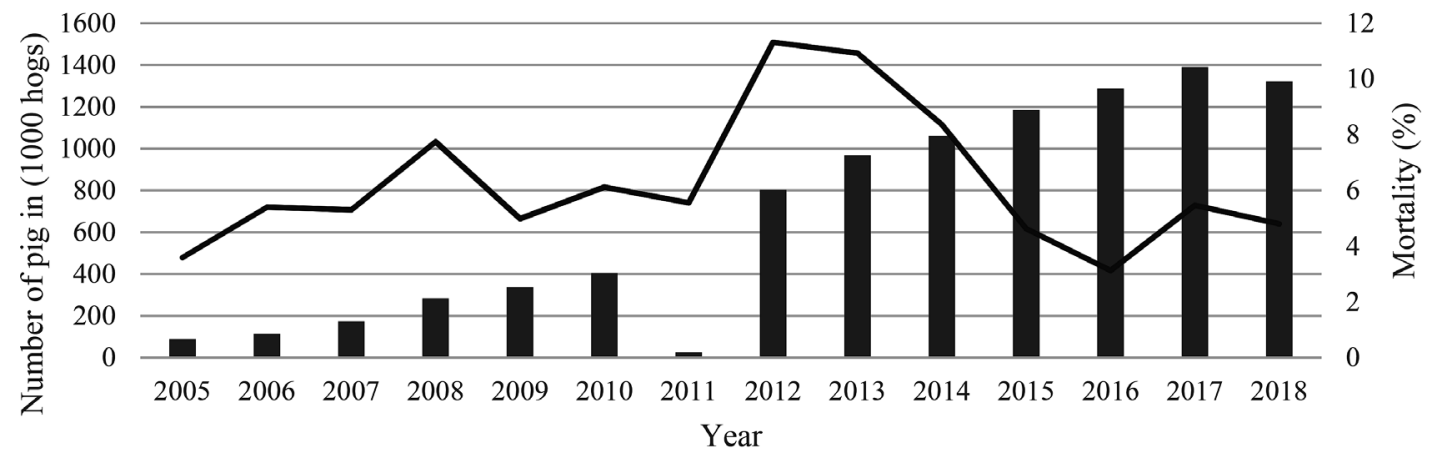

No of pig in $\quad$ Annual pig death and culling

Source: Own survey

Fig. 3. Number of hogs raising, average annual mortality of a leading contractor, 2005-2018.

prevention at farm level rather than market risk mitigation. The variation of price and lack of information prevent themselves from decision making.

From the national and regional context, policies regarding risk management of swine and pork industries are targeting mainly the risks prevention and mitigation instead of risk-sharing schemes (Tran, 2013). In developed countries, the prevalence of market-based instruments, disaster relief, social assistance or agricultural support program brings farmers several options for cop- ing with risk. Swine farmers can select various instruments for risk mitigation like futures and options, insurance, vertical integration, production/marketing contracts, spread sales, diversified financial investment or off-farm work (Moreddu, 2000). Swine farmers in the US can be protected by two livestock insurance products (Hoag, Thilmany, \& Green, 2006) or protect by Livestock Risk Protection (LRP) and Livestock Gross Margin (LGM). However, agricultural insurance in Vietnam has not developed (Thieu \& Van, 2014) and livestock insur- 


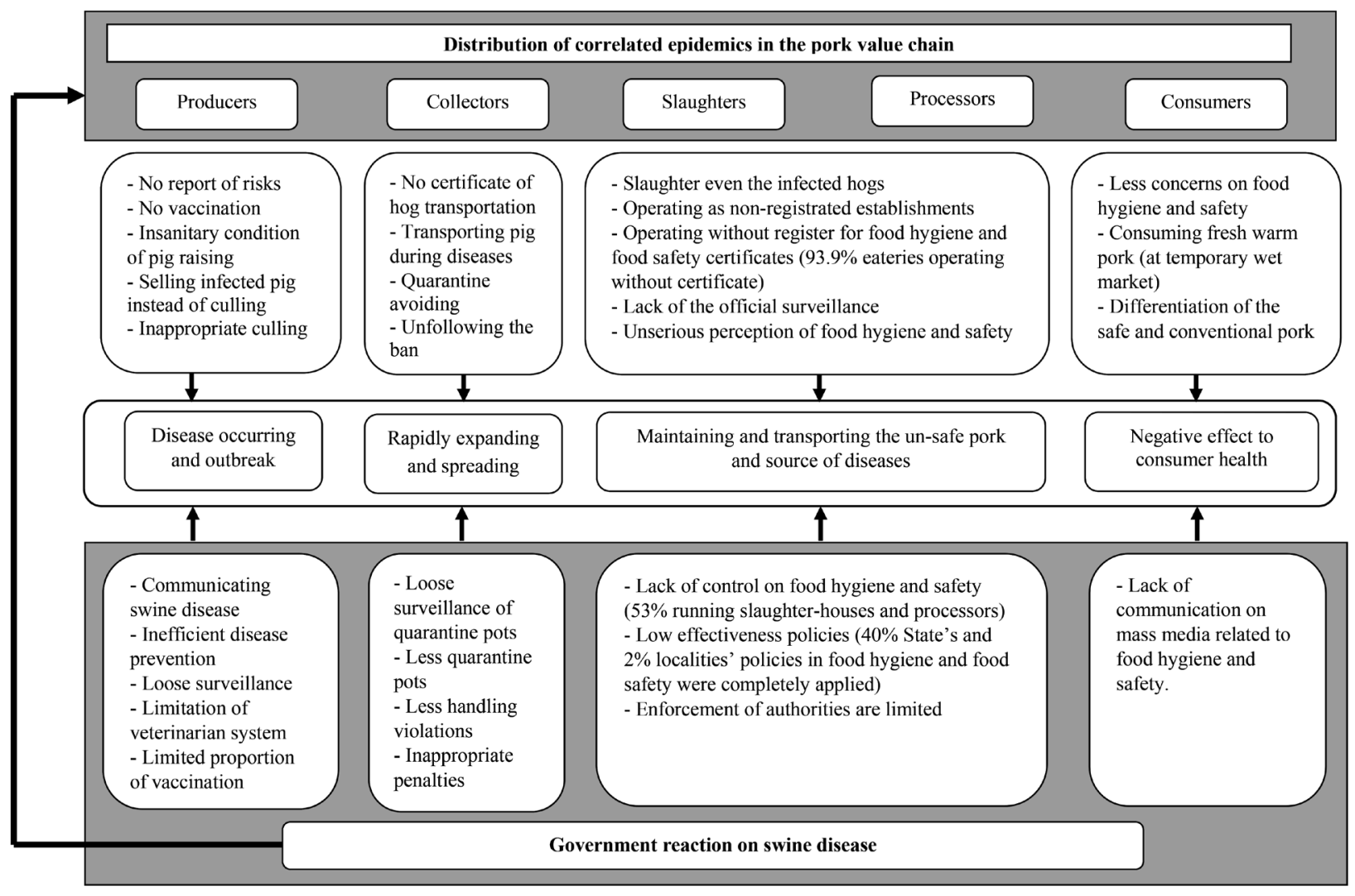

Source: Reproduced from Tran. D.T et al, (2011) with permission

Fig. 4. Outbreak and dispersion of correlated epidemics among actors in the pork chain of Vietnam.

ance does not exist. The main reasons were the high moral hazard, high transaction cost, and the unprecise, out-of-date time-series data (Skees, 1999; Dufhues, Lemke, \& Fischer, 2005). An application of livestock insurance requires reliable transparency time-series data, the rationality of farm size and supportive government policies (Tran, 2010). In those cases, vertical coordination/integration and contract farming are considered as appropriate risk sharing-scheme for farmers (Tran et al., 2011).

\section{Risk-sharing scheme through the formal contract agreement}

Insights the sharing scheme for mitigation of production and market risks

Correlated risks are the most important factors that restrain livestock insurance programs. Contract agreements fix the most popular risks like disease, hog price, animal feed price and production technique for the single large-scale farmers. Table 2 explains the unsystematic correlated risks that are almost covered in the contract contents. Up to date, the leading animal feed companies have provided contract agreements which varies from payment regulations and detail articles. Marketingbase contract also specifies some production terms to convey their quality requirements. Those contracts share the crucial straits ensuring the sharing-schemes among two parties:

Firstly, this is the full bilateral written contract agreements. Contractors offer specific contents that are negotiated with a single farmer. These agreements include production condition, risk sharing, and marketing terms. The contractor manages over the production process controlling quantity and quality of input flows from breeding to hog marketed. This contract farming is unable to be transferred to the third party like the future contract in the financial market. The rate per kilo of live hog increased is the basis for payment instead of the fixed price prior to starting the first production cycle. The contract also defines irresistible cases which are shared by both parties and actively provide strategy of copying with moral risks for contractors. Condition for selling product is also included.

Secondly, two parties agree on the long-term contract. Popularly, the first five-year contract can be extended with another three-year agreement followed by the annual validation. In the extreme case (farm leasing agreement), it is extended to a minimum fifteenyear contract. The long-run duration is expected to bring benefit to the farmer to cover initial investment and purport profit. The contract is unlimitedly extended, but it must be negotiated six months before the liquidation.

Thirdly, agreements signed between two parties are notarized by local People's Committee at the commune level. This ensures that farmers are the legal residents. The contract agreement follows different Laws in Vietnam depending on company typology of contractors. 
Table 2. Risk sharing of the parties in formal contract farming in the swine sector

\begin{tabular}{|c|c|c|}
\hline & Farmer (contractee) & Company (contractor) \\
\hline Production & $\begin{array}{l}\text { Invest in pig housing; managing labor and } \\
\text { entail contract farm (sows or hog) }\end{array}$ & $\begin{array}{l}\text { Provide and control the quality of breeds (exot- } \\
\text { ic), compound animal feed, vaccination, medi- } \\
\text { cine, technical staff, indirect management (con- } \\
\text { sulting, supportive activities) }\end{array}$ \\
\hline Benefit & $\begin{array}{l}\text { Stable total payment (compensate) from the } \\
\text { contractor, as follows (on average): } \\
\text { - For breeding: US } \$ 7.3-11.4 \text { per suckling } \\
\text { - For live hog: around } \$ 0.11-0.18 \text { per kilogram } \\
\text { of hog increased }\end{array}$ & $\begin{array}{l}\text { Receiving all breeds and/or live hogs (as qualified } \\
\text { amounts and quality) } \\
\text { Reducing hog production cost through cut-down } \\
\text { transaction cost, value-added tax on animal feed, } \\
\text { and tax on enterprise; creating a stable channel } \\
\text { for animal feed sales }\end{array}$ \\
\hline $\begin{array}{l}\text { Risk sharing } \\
\text { agreements }\end{array}$ & $\begin{array}{l}\text { - Disease prevention: cost of hygiene and } \\
\text { biosafety control, part of sterilization, integrat- } \\
\text { ed farm management, environmental treat- } \\
\text { ment } \\
\text { - Sharing loss of mortality: farmer bear the } \\
\text { loss of cut-down yield, payment rate, labor } \\
\text { cost using until the pig culled out; } \\
\text { - Negotiating for higher payment due to the } \\
\text { increasing cost of facilities }\end{array}$ & $\begin{array}{l}\text { - Disease prevention: cost of sterilization, vacci- } \\
\text { nation, technical prevention; compensate for } \\
\text { environmental treatment } \\
\text { - Sharing mortality loss: Contractor bears the } \\
\text { cost for breeds, animal feed, and facilities con- } \\
\text { sumed, labor cost (technical staffs) until culling; } \\
\text { - Support in case of increase price of facilities }\end{array}$ \\
\hline Systematic risks & $\begin{array}{l}\text { In the case of majeure (war, disasters, system- } \\
\text { atic disease, fire, etc), the farmer is free of } \\
\text { penalty and must bear own damage. }\end{array}$ & $\begin{array}{l}\text { The majeure is not the breaking contracting } \\
\text { case. No payment or compensation is required to } \\
\text { the contractor. Both parties must cover own } \\
\text { damage. }\end{array}$ \\
\hline
\end{tabular}

Source: Own survey

The domestic company's contract follows Civil Code while the foreign investor abides the Commerce Law.

Fourthly, farmers are required to control the lands before participating in the agreements. This links the development of the contract with the land use policies. The encouraging policy on agricultural land for husbandry has a positive impact on the establishment of a contract farm. The farmer has a larger area of land might invest by themselves to be independent farmers or participated in contract with the delegation on management over the production process to the contractors as following contents.

\section{Sharing the key unsystematic correlated risk in swine production}

Contents of production management contract summarized in Table 3 have shown some articles ensure the prevention of production risks. Payment regulation in Table 4 shows specific compensate amount of the following calculation, which encompass three parts the fixed terms, encourage terms and reduction.

$$
\begin{aligned}
\text { Fixed compen- } \\
\text { Pate base on the } \\
\text { increased weight } \\
\text { of the hog }
\end{aligned}+\begin{aligned}
& \text { Encouraging } \\
& \text { compensation }
\end{aligned}
$$

\section{- Deduction amount}

Encouraging compensation varies from contractors. It refers to the unusual support to prevent the expansion of epidemic disease like PRRS, FMD, etc. Some companies focus on sterilization, for example, C.P. Vietnam
Company support 0.5 million VND (25USD/production cycle for the less than 250- pigs head farm, that amount is doubled for farm raising the higher number of pigs. The deduction of payment frequently refers to the use of wrapping feed or drugs packages. Farmers must pay from 300-500 VND for a package used at the farm. This tiny amount is often concerned with the control for efficient utilization of feed and drugs at the farm. In some cases, farmers are required a payment if they use facilities to exceed the standard amount negotiated as mentioned in Figure 5 and Table 5. Compensate and deduction base on the controlling maturity, weight, and feed used. The differences between real feed consumption ration (FCR) are identified for each production cycle. In addition, the contractor prevents moral risk through this calculation.

Inevitably, each company provides their own way to prevent ethical risk. Farmers are not allowed to raise another pig at the farm under contract. Pigs death or culled belong to contractors that must be disposed. The number of death or total weight of the pig culled out are not calculated in the yield (output) for payment. This is the sharing of both parties. The contractor covers the cost of the breed, feed, medicine, and other facilities while the farmer lost their paymen-yield and expense for labor, energy, and others. Table 6 mentions the coping with the ethical risk of the contractees. In addition, the contractor prevents the moral risk by controlling the differences between standard and real Feed Conversion Ratio (FCR). It is noted that an average production cycle lasts around 90 days with the breeds used in current contracts. 
Table 3. Summary of production specifications

\begin{tabular}{|c|c|c|}
\hline & FDI company & Domestic company \\
\hline $\begin{array}{l}\text { Shelter, pig } \\
\text { housing (piggery) }\end{array}$ & $\begin{array}{l}\text { The contractor providing technical standard for } \\
\text { housing and design }\end{array}$ & $\begin{array}{l}\text { The offering of a technical standard for housing } \\
\text { and design }\end{array}$ \\
\hline Breeding & $\begin{array}{l}\text { Exotic breeds (suckling, piglet) } 18-30 \text { days, minimum } \\
\text { of } 4.0 \mathrm{~kg} \text { of weight }\end{array}$ & $\begin{array}{l}\text { Minimum weight in is } 5.0 \mathrm{~kg} \text {, the number of } \\
\text { suckling vary around } 10 \%\end{array}$ \\
\hline Necessary inputs & $\begin{array}{l}\text { Processed feed, vaccine, veterinary medicine, and } \\
\text { other facilities rather than veterinary tools... are } \\
\text { provided by the contractor. Cover of the packaging of } \\
\text { inputs is returned to the firms after use. }\end{array}$ & $\begin{array}{l}\text { Provide according to contractor's requirement; } \\
\text { Collecting all bottles, dreg, cans, or packaging of } \\
\text { feed, wrapping (pay 500VND/feed package for } \\
\text { using) }\end{array}$ \\
\hline $\begin{array}{l}\text { Technical support } \\
\text { and monitoring }\end{array}$ & $\begin{array}{l}\text { Contractor send technical staffs directly to the farms. } \\
\text { Supports include disease prevention, monitoring and } \\
\text { supervising, encouraging the technical practice }\end{array}$ & $\begin{array}{l}\text { Like the FDI companies; firms have its own way } \\
\text { to train and manage their staffs. }\end{array}$ \\
\hline $\begin{array}{l}\text { Postponing } \\
\text { (pausing time) }\end{array}$ & $1-3$ months if necessary & Specify in detail (see the payment rate) \\
\hline $\begin{array}{l}\text { Book-keeping and } \\
\text { auditing }\end{array}$ & $\begin{array}{l}\text { Providing the book-keeping form to the farmer; } \\
\text { monthly checking the insufficient/exceeded amount of } \\
\text { pig head or processed feed }\end{array}$ & $\begin{array}{l}\text { Provide book-keeping form; Weekly, insufficient/ } \\
\text { exceeded the amount of pig head or feed }\end{array}$ \\
\hline $\begin{array}{l}\text { Environmental } \\
\text { protection }\end{array}$ & Support through the norms in Regulation of payment & No support; fee covered by farmers \\
\hline Payment & $\begin{array}{l}\text { Transferring to farmer's bank account within } 21 \text { days } \\
\text { after finishing production cycle based on the yield (in } \\
\text { the receipt) and regulations of payment. Due to } \\
\text { negotiation about the production quality, the } \\
\text { transferring may be delayed. }\end{array}$ & $\begin{array}{l}\text { Via transferring to farmer's bank account; no } \\
\text { specific agreements }\end{array}$ \\
\hline $\begin{array}{l}\text { Contract to finish } \\
\text { and extend }\end{array}$ & $\begin{array}{l}\text { The negotiation for extending is conducted } 6 \text { months } \\
\text { before liquidation; contractor must remove all facilities } \\
\text { out of farm while the contract is finished. }\end{array}$ & $\begin{array}{l}\text { The negotiation for extending is conducted } \\
6 \text { months before liquidation }\end{array}$ \\
\hline
\end{tabular}

Source: Own survey

Table 4. Payment regulation for the contractee

Unit: VND per kilogram of hog increased

\begin{tabular}{|c|c|c|}
\hline Items & FDI contractor & Domestic firm \\
\hline \multicolumn{3}{|l|}{ Fix terms } \\
\hline $\mathrm{R}_{1}$ Fix compensate for outsourcing fattening (VND)* & 1600 & 2480 \\
\hline $\mathrm{R}_{2}$ Managing grade (maximum 100 point) (VND/kg & 100 & 100 \\
\hline $\mathrm{R}_{3}$ Compensate for energy use & 150 & 200 \\
\hline $\mathrm{R}_{4}$ Compensate for environmental treatment & 150 & 150 \\
\hline $\begin{array}{l}R_{5} \text { Compensate for efficient utilization of animal feed } \\
\left(\mathrm{D}=\mathrm{FCR}_{\text {real }}-\mathrm{FCR}_{\text {standard }}\right)\end{array}$ & $\begin{array}{l}\text { Min }-155, \max \\
350\end{array}$ & $10 * \mathrm{D} * \mathrm{~W}$ \\
\hline $\begin{array}{l}\mathrm{R}_{6} \text { Special rate if difference } \mathrm{D} \text { less than }-0,2 \\
\text { (or } \mathrm{FCR}_{\text {standard }}-\mathrm{FCR}_{\text {real }}>0.2 \text { ) }\end{array}$ & $30-120$ & None \\
\hline $\mathrm{R}_{7}$ Compensate for controlling mortality & 200 (max), specify in detail & specify in detail \\
\hline $\mathrm{R}_{8}$ Compensate for improving cooling system & 300 & No specified \\
\hline $\begin{array}{l}\mathrm{R}_{9} \text { Compensate for a contract signed since April 01st, } 2008 \\
\text { (due to construction cost rising) }\end{array}$ & 530 & No specified \\
\hline
\end{tabular}

Note: * The fixed term varies from firms, FCR: Feed Consumption Ratio 

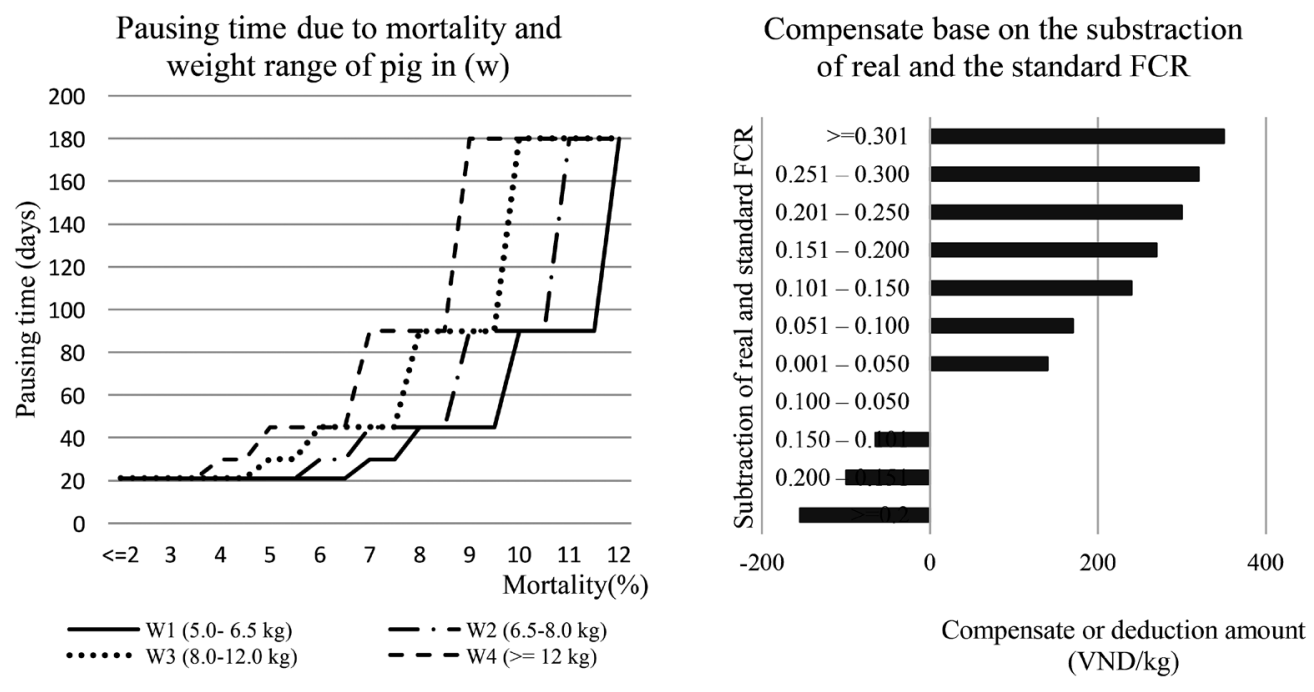

Source: Own survey

Fig. 5. Regulations on productions pausing and efficient use of feed.

Table 5. Compensate and deduction base on mortality and the average weight in

\begin{tabular}{|c|c|c|c|c|}
\hline \multirow[b]{3}{*}{ Mortality r (\%) } & \multicolumn{4}{|c|}{ Unit: VND/kg of weight increased } \\
\hline & \multicolumn{4}{|c|}{ Range of average weight in w (kg) } \\
\hline & w1 (5.0-6.5) & w2 (6.5-8.0) & w3 (8.0-12.0) & $\mathrm{w} 4(>=12)$ \\
\hline$<=2$ & 300 & 300 & 300 & 300 \\
\hline $2-2.5$ & 300 & 300 & 250 & 250 \\
\hline $2.5-3$ & 300 & 250 & 200 & 200 \\
\hline $3.0-3.5$ & 300 & 250 & 200 & 150 \\
\hline $3.5-4.0$ & 250 & 200 & 150 & 100 \\
\hline $4.0-4.5$ & 250 & 200 & 150 & $£=1000(4-r) q$ \\
\hline $4.5-5$ & 200 & 150 & 100 & \\
\hline $5.0-5.5$ & 200 & 150 & $£=1000(5-r) q$ & \\
\hline $5.5-6.0$ & 150 & 100 & & \\
\hline $6.0-6.5$ & 150 & $£=1000(6-r) q$ & & \\
\hline $6.5-7.0$ & 100 & & & \\
\hline$>7.0$ & $£=1000(7-r) q$ & & & \\
\hline
\end{tabular}

Note: $r$ : actual mortality (\%), q: total weight increased of pig herd ( $\mathrm{kg})$, £: deduction (VND)

Source: Own survey

Table 6. Coping with ethical risk

\begin{tabular}{|c|c|}
\hline FDI company & Domestic company \\
\hline $\begin{array}{l}\text { Amount of payment (million Vietnam Dong) if the } \\
\text { number of pig head is unequal to the one had been } \\
\text { signed in the contract: } \\
\qquad £ \text { (milion } \mathrm{VND})=\left\{\begin{array}{l}5 \mathrm{WPQ}, \text { if } \mathrm{W} \geq 25 \mathrm{~kg} \\
3 \mathrm{Q} \text { if } 4 \leq \mathrm{W}<25 \mathrm{~kg}\end{array}\right. \\
\text { where: } \mathrm{W} \text { is the average weight of the entire farm at } \\
\text { the time } t, \mathrm{P} \text { is the price of pig provided by the } \\
\text { contractor at the time } t, Q \text { is the number of pig } \\
\text { heads different from the contracted amount. }\end{array}$ & $\begin{array}{l}\text { Amount of payment (million Vietnam Dong) if the } \\
\text { number of pig head is unequal to the one had been } \\
\text { signed in the contract: } \\
£ \text { (million VND) = 8Q } \\
\text { where: } Q \text { is the number of pig heads different from } \\
\text { the contracted amount. }\end{array}$ \\
\hline $\begin{array}{l}\text { Amount of punishment (million VND) if the number } \\
\text { of feeds provided to the farm is unequal to the one } \\
\text { had been signed in the contract: } \\
£=5 \mathrm{PQ} \\
\text { Where: P is the price of similar commodity provided } \\
\text { by the contractor at the time } t\end{array}$ & $\begin{array}{l}\text { Amount of punishment (million VND) if the number } \\
\text { of feeds provided to the farm is unequal to the one } \\
\text { had been signed in the contract: } \\
£(\text { million VND) }=0.04 \mathrm{Q} \\
\text { Where: } \mathrm{Q} \text { is the number of feed }(\mathrm{kg}) \text { differs from the } \\
\text { contracted amount at time } t\end{array}$ \\
\hline
\end{tabular}




\section{Discussion}

Formal contract agreements are adaptations of the ones in industrialized countries. It widely used to govern the production and marketing of agricultural commodities. Like in the US, EU pork produced has been mostly been vertically integrated or coordinated through contracts (Lawrence, Rhodes, Grimes, \& Hayenga, 1997; Rehber, 2007). Comparing to this alternative, contract agreement retains higher profit intensive for grower effort, on-farm diversification, and the use of localized knowledge. Comparing to the spot market, contract agreement is an essential tool for managing risk; contracts provide incentives for farmers to invest in specialized equipment and skills to produce hogs with a desirable attribute; and the contract can reduce procesing costs of the firm by ensuring steady large flows of uniform agricultural products (MacDonald, 2015). Contractor also develops an extra stable animal feed channel via the contract farms. When the holding capacity of hog increasing, the power of contractors in the relation with hog traders, the slaughter, processors and the modern retailers have been strengthened.

Contracts can reduce farmer risks, but that does not appear to be the primary reason for their growth (MacDonald et al., 2004). It does not cover the systematic correlated risk such as epidemics which expand to the interregional of the country. The African Swine Fever (ASF) has swept over Vietnam in April 2019 led some of the contract farms into termination due to the majeure circumstance (irresistible or unforeseen event). The reduction of the market price in 2017-2018 is another evidence. The scheme protects the contract farmers, but contractors (as the large-scale hog holders) must bear the losses if they do not have own processing and distribution system.

The contract agreement may be considered as an out-sourcing contract, where single farmers are taking part in a specific production process of a firm. This also can refer to an out-source labor agreement. However there is no professional organization represent them in negation with the company at the beginning or amending agreements. Payment regulations do not specify clear enough the standard feed consumption ratio, which affects directly benefit of farmers. FCR standard is calculated then put into account. In addition, the payment regulation may not cover the opportunities cost of landown, adverse selections or the second-best options. It is also necessary to reveal the decision making process of farmers into a contract, and the contract enforcement in the swine industry.

\section{CONCLUSION AND POLICY IMPLICATION}

Hog producers in Vietnam have suffered several types of risks, of which epidemic disease and market risks impact mainly. These are the correlated risks that affect producers from farm-level to the interregional scope of the country. Farmers have chased for the risk prevention and mitigation strategies instead of the risk coping through the market-based or government-based instruments like livestock insurance, and hedging because these do not exist or undevelop. Formal contracts for the large-scale (hog and sows) farms are the rational selections. Contents of contract agreement vary between companies in some specific payment terms, but they have similar characteristics. The formal contracts include production management contract offering by animal feed companies and marketing contract proposed by the processors. Both have stipulated long-term validation, fixed-benefit, and prescribed responsibilities in managing production, quality, and quantities of products. They also cover almost unsystematic risks of small-scale producers. However, it is not the perfect instrument due to the inherent limitation in solving the structured risk of single mega-scale producers. The development of the formal contract scheme has raised the rationale for the future theoretical and empirical studies to optimize contract scheme for actors involved. In the un-existence of financial instrument for risk mitigation, contract farming, and vertical integration should be promoted as essential tools for managing with risks.

\section{AUTHOR CONTRIBUTIONS}

D. D. DONG, R. LIU and M. MORITAKA conceived of the presented idea. D. D. DONG developed the framework, collected data, wrote first draft. M. MORITAKA and R. LIU verified the analytical methods, findings and proofread the manuscript. S. FUKUDA encouraged, supported D. D. DONG to deal with the idea and supervised this work. All authors discussed the results and contributed to the final manuscript.

\section{ACKNOWLEDGEMENTS}

We would like to thank the QR program at Kyushu University, Japan for supporting this work.

\section{REFERENCES}

Costales, A., \& Catelo, M. A. O. 2008 Contract farming as an institution for integrating rural smallholders in markets for livestock products in developing countries: I Framework and applications. Pro-Poor Livestock Policy Initiative

Dong, D. D., Liu, R., Moritaka, M., \& Fukuda, S. 2018 a Contribution of vertical integration to the reform of value chain governance: an evidence from pork industry in Vietnam. Symposium on East Asian Agricultural Economics: The 4th Industrial Revolution and Agruculture- Changes, Challenges and Tasks, 213-214. Pyeongchang

Dong, D. D., Liu, R., Moritaka, M., \& Fukuda, S. 2018 b Governance reform of agro-food value chain through vertically integrated and contract farming scheme: an evidence from the pork value chain in Viet Nam. International Symposium on Agricultural, Food, Environmental and Life Sciences in Asia, 2018. Chungcheon

Dong, D. D., Moritaka, M., \& Fukuda, S. 2015 Impact of formal contract farming scheme on household's income: A case study in swine production in Hanoi city, Vietnam. In A. and R. E. S. of J. The Food Ed. , Japanese Journal of Food, Agricultural and Resource Economics. 66:1, July 2015 p. 67. Kumamoto City

Dufhues, T. B., Lemke, U., \& Fischer, I. 2005 Constraints and potential of livestock insurance schemes: A case study from 
Vietnam

FAOSTAT. 2018 FAOSTAT: live animals data. Retrieved February 15, 2019, from http://www.fao.org/faostat/en/\#data/QA

Giap, N. Van. 2015 Animal husbandry market in Vietnam: restructure toward improving competiviness. Hanoi: Hong Duc publisher in Vietnameses

Hardaker, J. B., Lien, G., Anderson, J. R., \& Huirne, R. B. M. 2015 Coping with risk in agriculture: Applied decision analysis. $C A B I$

Hoag, D. L., Thilmany, D. D., \& Green, J. W. 2006 The economics of livestock disease insurance: concepts, issues and international case studies. CABI

Huong, N. T., \& Nanseki, T. 2015 Households' Risk Perception of Pig Farming in Vietnam: A Case Study in Quynh Phu District, Thai Binh Province. The Japanese Journal of Rural Economics, 17: 58-63

IPsos. 2017 The Vietnam swine market: A Bumpy Road Ahead. Retrieved from https:/www.ipsos.com/sites/.../The-VietnamSwine-Market.pdf

Lawrence, J. D., Rhodes, V. J., Grimes, G. A., \& Hayenga, M. L. 1997 Vertical coordination in the US pork industry: Status, motivations, and expectations. Agribusiness: An International Journal, 13: 1, 21-31

MacDonald, J. M. 2015. Trends in agricultural contracts. Choices, 30: $3,1-6$

MacDonald, J. M., Perry, J., Ahearn, M. C., Banker, D., Chambers, W., Dimitri, C., ... Southard, L. W. 2004 Contracts, markets, and prices: Organizing the production and use of agricultural commodities

Moreddu, C. 2000 Overview of farm household strategies and government intervention. OECD Workshop on Income Risk Management, Paris, France, 15-16 May 2000, 17-61. Organisation for Economic Cooperation and Development OECD

Nghi, N. Q., Anh, T. Q., Oanh, N. D. Y., \& Phong, V. V. 2013 Building the linkage model to prevent agricultural risks on pig production of farmer households in Can Tho City. Can Tho University Journal of Science, 2013: 25, 52-60 (original in Vienamese)

Nguyen, T. T. H., \& Pham, V. H. 2016 Behaviors of Farmers Towards Pig Diseases in Hung Yen Province. Vietnam Journal of Agricultural Sciences, 14: 2, 143-150 (original in Vietnamese)

Nguyen, T. Hao, Nguyen, Q. C., Kabango, A. N., \& Pham, T. D. 2018 Vietnamese Consumers' Willingness to Pay for Safe Pork in Hanoi. Journal of International Food \& Agribusiness Marketing, 1-22. DOI: 10.1080/08974438.2018.1533506

Nguyen, Thi Huong, Nanseki, T., \& Chomei, Y. 2016 Households' Perception of Risk Management Strategies in Pig Production in
Vietnam. Japanese Journal of Farm Management, 53: 4 90-95

OECD. 2018 Meat consumption indicator . Retrieved February 15, 2019, from OECD data website: https://data.oecd.org/agroutput/meat-consumption.htm

OECD. 2009 Managing risk in agriculture: a holistic approach. OECD publishing

Pham, H T T, Antoine Moussiaux, N., Grosbois, V., Moula, N., Truong, B. D., Phan, T. D., ... Rukkwamsuk, T. 2017 Financial impacts of priority swine diseases to pig farmers in Red River and Mekong River Delta, Vietnam. Transboundary and Emerging Diseases, 64: 4, 1168-1177

Pham, Hoa T T, Peyre, M., Trinh, T. Q., Nguyen, O. C., Vu, T. D., Rukkwamsuk, T., \& Antoine-Moussiaux, N. 2017 Application of discrete choice experiment to assess farmers' willingness to report swine diseases in the Red River Delta region, Vietnam. Preventive Veterinary Medicine, 138: 28-36

Prowse, M. 2012 Contract farming in developing countries: a review. Paris: Agence Française de Développement, 2012. A Savoir No. 12: AFD

Rehber, E. 2007 Contract farming: Theory and practice. ICFAI Books

Rhodes, V. J. 1995 The industrialization of hog production. Review of Agricultural Economics, 107-118. https://doi.org/ https://doi.org/10.2307/1349725

Skees, J. 1999 Agricultural insurance in a transition economy. Agricultural Finance and Credit Infrastructure in Transition Economies. Proceedings of OECD Expert Meeting, Moscow, February 1999, 233-249

Sporleder, T. L. 1992 Managerial economics of vertically coordinated agricultural firms. American Journal of Agricultural Economics, 74: 5, 1226-1231

Thieu, D. H. T., \& Van, T. L. 2014 Agricultural insurance market development the role of Vietnam Government. Int. J. Econ. Commer. Manage., Available from Http://Ijecm. Co. Uk/ ISSN23480386

Tran, D. T. 2010 Pig diseases insurance: Principles and requirements for application in Vietnam. Economic Studies, 11: Novemeber, 55-59 (original in Vietnamese)

Tran, D. T. 2013 Risk management policies for pig raising sector in Vietnam. Economics and Development, 192: 64-71(original in Vietnamese)

Tran, D. T., Nguyen, D. L., Le, N. H., \& Nguyen, T. M. T. 2011 A study on risk management policies in swine industry of Vietnam. Program No.BNN2009/1. Hanoi (original in Vietnamese)

Tran, D. T., \& Nguyen, T. M. T. 2012 Risks analysis of pig sector in Vietnam. Economics Studies, 414: 53-60 (Original in Vietnamese) 
